\title{
Emergency medicine resident wellness: Lessons learned from a national survey
}

\author{
Ahmed Taher, MD*; Alexander Hart, MD*; Neil Dinesh Dattani, $\mathrm{MD}^{\dagger}$; Zafrina Poonja, $\mathrm{MD}^{\ddagger}$; \\ Christina Bova ${ }^{\S}$; Glen Bandiera, MD, MEd*ף; Kaif Pardhan, MD*\|
}

\author{
CLINICIAN'S CAPSULE \\ What is known about the topic? \\ Emergency medicine (EM) residents face many wellness \\ challenges during residency. \\ What did this study ask? \\ What was the current landscape of Canadian EM resident \\ wellness? \\ What did this study find? \\ Canadian EM residents face a multitude of psychosocial \\ and physical wellness challenges, while supports may \\ not be adequate. \\ Why does this study matter to clinicians? \\ Opportunities exist to further investigate resident well- \\ ness with validated tools, engage stakeholders, and \\ advance the EM resident wellness agenda.
}

\section{ABSTRACT}

Objectives: Emergency medicine (EM) residents face many challenges during residency. Given the negative effects of residency training and the paucity of information on EM resident wellness experiences, we conducted a national survey to characterize the current landscape of Canadian EM resident wellness.

Methods: A cross-sectional study of Canadian EM residents was done using an online survey created by a Canadian Association of Emergency Physicians Resident Section working group on wellness. Surveys were sent to chief residents in Canadian EM residency programs accredited by either the Royal College of Physicians and Surgeons of Canada (RCPSC) or the College of Family Physicians of Canada (CFPC) in English and French.

Results: Thirty-one EM programs were contacted (14 RCPSC and 17 CFPC), and $216(42 \%)$ responses were collected. A multitude of negative wellness impacts were noted, including falling asleep while driving and motor vehicle collisions postnight or during a 24-hour call shift. Moreover, experiences included verbal, physical, and sexual harassment, and reports of low mood and suicidal ideation. Wellness supports were not always accessed after negative incidents. Residents reported deficits in formal wellness instruction, with support for formal EM program wellness time.

Conclusions: Canadian EM residents face a multitude of psychosocial and physical wellness challenges, while supports may not be adequate. Opportunities exist to further investigate resident wellness with validated tools, engage stakeholders, and advance the EM resident wellness agenda.

\section{RÉSUMÉ}

Objectif: Les résidents en médecine d'urgence (MU) font face à de nombreuses difficultés durant leur programme. Compte tenu des effets néfastes de la formation au niveau de la résidence et du peu d'information sur l'expérience de bienêtre que vivent les résidents en $\mathrm{MU}$, nous avons mené une enquête nationale afin de brosser le tableau du bien-être des résidents en MU au Canada.

Méthode: Une étude transversale menée parmi les résidents en $\mathrm{MU}$ au Canada a été réalisée à I'aide d'un questionnaire d'enquête en ligne, élaboré par un groupe de travail, sur le bien-être, de la section des résidents de l'Association canadienne des médecins d'urgence. Des questionnaires rédigés en français ou en anglais ont été envoyés aux résidents en chef des programmes de résidence en $\mathrm{MU}$, agréés par le Collège royal des médecins et chirurgiens du Canada (CRMCC) ou par Le Collège des médecins de famille du Canada (CMFC).

Résultats: Nous avons communiqué avec les responsables de 31 programmes de MU (CRMCC : 14; CMFC : 17) et le taux de réponse global a atteint $42 \%$ (216 questionnaires recueillis). De nombreux effets néfastes de la résidence sur le bien-être ont été relevés, par exemple s'endormir au volant ou encore avoir un accident d'automobile après une nuit de travail ou une journée de garde de 24 heures. Des répondants ont aussi fait état de harcèlement verbal, physique ou sexuel, de même

From the *Division of Emergency Medicine; tFamily and Community Medicine, University of Toronto, ON; $¥$ Department of Emergency Medicine, University of Alberta, Edmonton, AB; §Canadian Association of Emergency Physicians, Ottawa, ON; ףSt. Michael's Hospital, Toronto, ON; and \|Sunnybrook Health Sciences Centre, Toronto, ON.

Correspondence to: Dr. Ahmed Taher, Department of Medicine, University of Toronto, 190 Elizabeth Street, Unit 3-805, Toronto, ON M5G 2C4; Email: ahmed.taher@mail.utoronto.ca 
que d'humeur maussade ou d'idées suicidaires. De plus, il n'était pas toujours possible d'obtenir du soutien en matière de bien-être à la suite d'événements fâcheux. Enfin, les résidents ont indiqué un manque de formation structurée en matière de bien-être et ont accueilli favorablement de l'idée que du temps soit consacré au bien-être dans le programme de MU.

Conclusion: Les résidents en $\mathrm{MU}$ au Canada font face à une multitude de difficultés d'ordre physique et psychosocial sur le plan du bien-être, tandis que les mesures de soutien, elles, ne sont pas toujours à la hauteur des besoins. Toutefois, il existe des possibilités d'approfondir la question du bien-être des résidents à l'aide d'outils validés, de faire appel à des intervenants et de promouvoir le programme d'action pour le bien-être des résidents en $\mathrm{MU}$.

Keywords: Wellness, medical education, emergency medicine

\section{INTRODUCTION}

Residency training has been shown to have a negative impact on physical, emotional, and social well-being. ${ }^{1}$ Residents experience high rates of burnout, ${ }^{2,3}$ depression, ${ }^{4}$ emotional exhaustion, ${ }^{5}$ and social strain. ${ }^{6}$ Shift work for emergency medicine (EM) residents also poses long-term risks, including metabolic syndrome ${ }^{7,8}$ and cardiovascular disease. ${ }^{9}$ Moreover, learning environments include intimidation ${ }^{1}$ and personal safety concerns. ${ }^{10}$

Accredited Canadian EM training includes two streams: those leading to a certification through either the Royal College of Physicians and Surgeons of Canada (RCPSC) or the College of Family Physicians of Canada (CFPC). Neither EM stream wellness experience has been well characterized. Given the negative effects of residency training and the paucity of information on EM resident wellness experiences, we conducted a national cross-sectional study to characterize the current landscape of Canadian EM resident wellness.

\section{METHODS}

This was a cross-sectional study of Canadian EM residents. A Canadian Association of Emergency Physicians Resident Section (CAEP RS) wellness working group composed of four senior residents (AT, AH, ZP, ND) created a list of survey questions based on a CAEP wellness position statement ${ }^{11}$ and Resident Doctors of Canada (RDoC) survey ${ }^{1}$ topics. Survey questions were chosen by a working group member consensus. Several questions were discarded due to ambiguity after consultation with a survey methodologist (Appendix).

An anonymous survey link, along with study information, was sent to chief residents (CRs) of Canadian EM residency programs by email, with two follow-up emails over a 4-month period. Francophone programs received all information and the survey in French. CRs were then asked to forward the information to their residents. Total resident numbers were calculated from program websites, the Canadian residency matching service (CaRMS), ${ }^{12}$ and confirmation with programs. The study period was from January to May 2017. Two programs with the highest response rates were awarded \$250. A full list of survey questions is illustrated in the online Appendix. No program information was collected to maintain anonymity. Approval was obtained from the Research Ethics Board of Sunnybrook Health Sciences Centre.

\section{RESULTS}

A total of 511 Canadian EM residents were included, 31 EM programs were contacted (14 RCPSC and 17 CFPC), and a $42 \% \quad(n=216)$ response rate was obtained. A full list of responses and demographics is illustrated in the online Appendix. RCPSC residents comprised $25 \%(n=128)$, with most in their first 3 years of training. Forty-four respondents $(8.6 \%)$ did not specify their year.

EM residency experiences are illustrated in Tables 1 and 2. During residency training, 20\% $(n=103)$ reported falling asleep while driving post-night shift, or after a 24-hour call shift, and 3.5\% $(\mathrm{n}=18)$ were involved in a motor vehicle collision (MVC) post-night or during a call shift. Verbal, physical, and sexual harassment and assault occurred at varying levels by patients, accompanying persons, other residents, or faculty. During residency, 35\% $(\mathrm{n}=178)$ reported low mood, and $4.3 \%(n=22)$ reported suicidal ideation. Six percent $(n=14)$ reported social isolation. Overall, residents reported gaps in wellness instruction, with $34 \%(n=173)$ welcoming dedicated program wellness time and $31 \%(\mathrm{n}=160)$ for resilience training.

\section{DISCUSSION}

In this survey of Canadian EM residents, we identified a multitude of significant wellness challenges and 
Table 1. EM residency training experience survey responses

\begin{tabular}{|c|c|c|c|c|c|}
\hline \multicolumn{6}{|c|}{ During your residency training, have you experienced: } \\
\hline Questionlanswer & None & Once & $2-5$ times & $5+$ times & N/A \\
\hline Falling asleep at the wheel (post-night shift or post-call) & 98 & 56 & 38 & 9 & 0 \\
\hline Motor vehicle collision (post-night shift or post-call) & 182 & 17 & 1 & 0 & 1 \\
\hline Verbal harassment from patient or accompanying person & 33 & 21 & 88 & 59 & 0 \\
\hline Physical threats from patient or accompanying person & 92 & 41 & 55 & 13 & 0 \\
\hline Physical assault from patient or accompanying person & 167 & 22 & 12 & 0 & 0 \\
\hline Sexual harassment from patient or accompanying person & 151 & 20 & 26 & 4 & 0 \\
\hline Sexual assault from patient or accompanying person & 197 & 4 & 0 & 0 & 0 \\
\hline Verbal harassment from other residents & 117 & 32 & 39 & 13 & 0 \\
\hline Physical threats from other residents & 196 & 3 & 0 & 0 & 0 \\
\hline Physical assault from other residents & 200 & 0 & 0 & 0 & 0 \\
\hline Sexual harassment from other residents & 196 & 3 & 2 & 0 & 0 \\
\hline Sexual assault from other residents & 200 & 0 & 0 & 0 & 0 \\
\hline Verbal harassment from faculty or hospital staff & 102 & 32 & 51 & 15 & 1 \\
\hline Physical threats from faculty or hospital staff & 197 & 3 & 0 & 0 & 0 \\
\hline Physical assault from faculty or hospital staff & 199 & 1 & 0 & 0 & 0 \\
\hline Sexual harassment from faculty or hospital staff & 195 & 4 & 2 & 0 & 0 \\
\hline Sexual assault from faculty or hospital staff & 200 & 1 & 0 & 0 & 0 \\
\hline Needle stick injury & 114 & 59 & 28 & 0 & 0 \\
\hline Exposure to body fluids & 85 & 62 & 42 & 12 & 0 \\
\hline
\end{tabular}

Table 2. EM residency survey responses for frequency of experiences

\begin{tabular}{|c|c|c|c|c|c|}
\hline \multicolumn{6}{|c|}{ How would you describe the frequency you experience of the following over the past 6 months? } \\
\hline Questionlanswer & Never & Rarely & Sometimes & Often & Always \\
\hline Fatigue & 2 & 4 & 44 & 113 & 37 \\
\hline Daytime sleepiness (not post-call or night) & 4 & 12 & 74 & 87 & 23 \\
\hline Stress & 0 & 11 & 77 & 91 & 20 \\
\hline Anxiety & 7 & 51 & 71 & 57 & 14 \\
\hline Low mood & 22 & 64 & 78 & 31 & 5 \\
\hline Hopelessness & 96 & 63 & 28 & 11 & 2 \\
\hline Passive thoughts of wanting life to end & 154 & 29 & 12 & 5 & 0 \\
\hline Thoughts of self harm & 179 & 14 & 3 & 4 & 0 \\
\hline Thoughts of suicide & 178 & 14 & 6 & 2 & 0 \\
\hline Drinking alcohol or doing recreational drugs to cope & 112 & 44 & 33 & 11 & 0 \\
\hline
\end{tabular}

important opportunities for improvement. Burnout, mental health struggles, and concerns for safety such as MVCs were notable. These experiences support previously reported rates of burnout and decreased quality of life. ${ }^{2-4}$ Moreover, our rate of suicidal ideation is in keeping with previously reported rates in medical trainees of $4.4 \%$ to $14 \% .^{13-15}$

Responses suggest actionable areas for further investigation and mitigation. Resiliency training has previously shown positive effects on quality of life for staff physicians ${ }^{16}$ and residents. ${ }^{17}$ However, the need for more training needs to be reconciled with program curricula time limitations. The transition to Competence by Design (CBD) may provide an opportunity for this (a national working group of stakeholders should form to address this need).

Secondly, there is a low reported rate of seeking wellness resources, with some dissatisfaction when accessed. It would be important to determine whether this is due to a lack of knowledge of their existence or whether accessibility barriers exist. RCPSC and CFPC accreditation standards govern EM residency programs, ${ }^{18}$ which programs may be meeting, but there remains a deficit in EM residents accessing these 
resources. Therefore, residents need to be involved as stakeholders to inform future mitigation.

Several limitations were identified. The survey questions were not pilot tested on an independent sample of potential respondents but rather among the consensus committee. An external survey methodologist was also consulted. Although the questions seemed to have face validity, some improved clarity could have been achieved. We cannot determine any program-related patterns or biases due to the confidentiality inherent in our model. Low response rates were received from francophone $(\mathrm{n}=19)$ and CFPC training programs $(\mathrm{n}=44)$, as well as RCPSC senior residents; $8.6 \%$ of respondents did not answer the demographics section. Moreover, one program was not contacted (Saint John, New Brunswick) due to the inability to locate it on the CaRMS website. Although the overall response rate was $42 \%$, these limitations may impede national generalizations and the ability to make associations between subgroups.

\section{CONCLUSION}

Our exploratory survey suggested that Canadian EM residents are facing psychosocial and physical wellness challenges. These present opportunities to further investigate resident wellness with validated tools, engage stakeholders, and advance the EM resident wellness agenda.

\section{SUPPLEMENTARY MATERIAL}

To view supplementary material for this article, please visit https://doi.org/10.1017/cem.2018.416

Acknowledgements: We would like to acknowledge the assistance of the CAEP head office with the survey collection and analysis, and the University of Toronto Postgraduate Medical Education office for providing a survey methodologist.

Competing interests: The Canadian Association of Emergency Physicians (CAEP) head office supported this study, and two authors (AT, AH) were part of the CAEP wellness position statement working group.

\section{REFERENCES}

1. Canadian Association of Interns and Residents. Summary of key findings, 2013 national resident survey; 2013. Available at: http://residentdoctors.ca/wp-content/uploads/2015/08/ Key-Findings-2013-National-Resident-Survey.pdf (accessed 1 November 2017).
2. West CP, Shanafelt TD, Kolars JC. Quality of life, burnout, educational debt, and medical knowledge among internal medicine residents. FAMA 2011;306(9):952-60.

3. Martini S, Arfken CL, Churchill A, Balon R. Burnout comparison among residents in different medical specialties. Acad Psychiatry 2004;28(3):240-2.

4. Dyrbye LN, West CP, Satele D, et al. Burnout among US medical students, residents, and early career physicians relative to the general US population. Acad Med 2014;89 (3):443-51.

5. Kimo Takayesu J, Ramoska EA, Clark TR, et al. Factors associated with burnout during emergency medicine residency. Acad Emerg Med 2014;21(9):1031-5.

6. Landrigan CP, Rothschild JM, Cronin JW, et al. Effect of reducing interns' work hours on serious medical errors in intensive care units. $N$ Engl $\mathcal{F}$ Med 2004;351(18): 1838-48.

7. De Bacquer D, Van Risseghem M, Clays E, et al. Rotating shift work and the metabolic syndrome: a prospective study. Int 7 Epidemiol 2009;38(3):848-54.

8. Karlsson B, Knutsson A, Lindahl B. Is there an association between shift work and having a metabolic syndrome? Results from a population based study of 27,485 people. Occup Environ Med 2001;58(11):747-52.

9. Bøggild H, Knutsson A. Shift work, risk factors and cardiovascular disease. Scand 7 Work Environ Health 1999 Apr 1: 85-99.

10. Anglin D, Kyriacou DN, Hutson HR. Residents' perspectives on violence and personal safety in the emergency department. Ann Emerg Med 1994;23(5):1082-4.

11. Taher A, Crawford S, Koczerginski J, et al. Canadian Association of Emergency Physicians. Resident Section Position Statement on Resident Wellness. C7EM 2018;20 (5):671-84.

12. Canadian Resident Matching Service (CaRMS); 2017. Available at: https://www.carms.ca/en/ (accessed 1 November 2017).

13. Dyrbye LN, Thomas MR, Massie FS, et al. Burnout and suicidal ideation among US medical students. Ann Intern Med 2008;149(5):334-41.

14. Schwenk TL, Davis L, Wimsatt LA. Depression, stigma, and suicidal ideation in medical students. FAMA 2010;304 (11):1181-90.

15. Tyssen R, Vaglum P, Grønvold NT, Ekeberg Ø. Suicidal ideation among medical students and young physicians: a nationwide and prospective study of prevalence and predictors. 7 Affect Disord 2001;64(1):69-79.

16. Sood A, Prasad K, Schroeder D, Varkey P. Stress management and resilience training among department of medicine faculty: a pilot randomized clinical trial. 7 Gen Intern Med 2011;26(8):858-61.

17. Howe A, Smajdor A, Stöckl A. Towards an understanding of resilience and its relevance to medical training. Med Educ 2012;46(4):349-56.

18. The Royal College of Physicians and Surgeons of Canada. Accreditation of residency programs; 2017. Available at: http://www.royalcollege.ca/rcsite/education-strategy-accred itation/pgme-training-programs/accreditation-residencyprograms-e (accessed 1 November 2017). 